primaries with a large, oblique, oblong, bright red patch at the end of the cell from the areole to near vein 2. Underside: both wings sooty brown: primaries with the red patch showing through as deep orange; secondaries with the costa broadly bright red to beyond its centre, the space between all the veins streaked with bright red and also in the cell.

Expanse $50 \mathrm{~mm}$.

Hab. Sierra Leone.

Type in my collection; two specimens.

XLVIII.-Description of a new Chameleon of the Genus Rhampholeon from Mashonaland. By G. A. Boulenger, F.R.S.

\title{
Rhampholeon Marshalli.
}

No spine on the inner surface of the digits, but each claw with a strong secondary cusp. Head once and two thirds as long as broad, very feebly raised behind; no parietal crest; large tubercles on the occipital region; a tubercular ridge on the temple, terminating in a subconical bony knob; no prominent supraciliary ridge; a small, soft, granular rostral appendage in the female*; no gular crest; a series of enlarged tubercles on each side below the lower jaw, from the chin to the arm. Body granular, with scattered larger

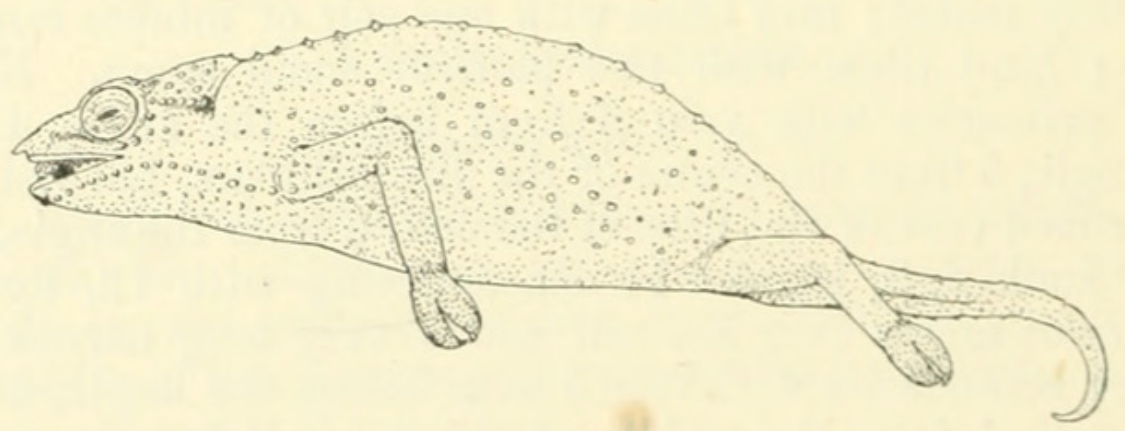

Rhampholeon Marshalli, natural size.

tubercles on the sides; a series of widely spaced subconical tubercles along the spine; no ventral crest. Tail about three fifths the length of head and body. The specimen, as preserved in spirit, is brownish on the body, variegated with

* It is probably much larger in the male. 
blackish, whitish on the belly and under the limbs; head blackish above and beneath.

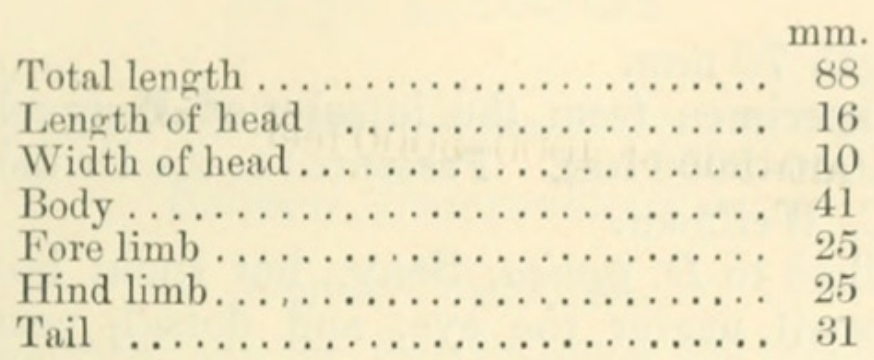

A single specimen, a gravid female, was found in the Chirinda Forest, S.E. Mashonaland, altitude 4500 feet, by Mr. Guy H. K. Marshall, and presented by him to the British Museum.

The discovery of a species of the genus Rhampholeon south of the Zambesi is one of very great interest. The Chirinda Forest, Mr. Marshall informs me, has a tropical insect-fauna quite distinct from that of the surrounding districts. Its reptile and batrachian fauna, when explored, is likely to afford further startling additions to South-African herpetology.

XLIX.-Description of a new Silurid Fish of the Genus Doumea, Sauvage, from Angola. By G. A. Boulenger, F.R.S.

\section{Doumea angolensis.}

Depth of body about $\frac{3}{4}$ its width, $10 \frac{1}{2}$ times in total length. Head strongly depressed, smooth above, once and $\frac{1}{3}$ as long: as broad, $5 \frac{1}{4}$ times in total length; snout obtusely pointed, projecting beyond the mouth, once and $\frac{1}{2}$ as long as postorbital part of head; internarial space a little nearer the eye than the end of the snout; diameter of eye 8 times in length of head, twice in interorbital width; maxillary barbel $\frac{1}{3}$ length of head, mandibular barbels a little shorter still; lips and barbels covered with large round papillæ. Occipital process narrow, half length of snout, widely separated from interneural shield. Dorsal I 7, first ray nearly as long as head. Anal I 7. Pectoral not longer than head, widely separated from the ventral, which just reaches origin of anal. Caudal peduncle $\frac{1}{4}$ of the total length. Yellowish brown above, whitish beneath; ill-defined dark bars across the 


\section{$2 \mathrm{BHL}$ Biodiversity Heritage Library}

1906. "Description of a new chameleon of the genus Rhampholeon from Mashonaland." The Annals and magazine of natural history; zoology, botany, and geology 18, 346-347. https://doi.org/10.1080/00222930608562624.

View This Item Online: https://www.biodiversitylibrary.org/item/63772

DOI: https://doi.org/10.1080/00222930608562624

Permalink: https://www.biodiversitylibrary.org/partpdf/60126

\section{Holding Institution}

University of Toronto - Gerstein Science Information Centre

\section{Sponsored by}

University of Toronto

\section{Copyright \& Reuse}

Copyright Status: NOT_IN_COPYRIGHT

This document was created from content at the Biodiversity Heritage Library, the world's largest open access digital library for biodiversity literature and archives. Visit BHL at https://www.biodiversitylibrary.org. 